Paulík, K.

\section{Psychologie práce a organizace: Vybrané kapitoly}

Ostrava, Ostravská univerzita 2018

Karel Paulík z Ostravské univerzity se dlouhodobě věnuje psychologii práce a organizace v rámci výzkumu i výuky. V loňském roce své zkušenosti shrnul do knihy, která pokrývá 26 témat, se kterými se psychologové v organizacích často setkávají. Těmto tématům věnuje 185 stran textu, takže kniha nabízí spíše široký přehled než podrobný vhled do jednotlivých problematik. Tento přehled může být podle mě užitečný zejména pro studenty psychologie a HR, pro zaměstnance nastupující na pozice $v$ HR a pro manažery, kteří si chtějí rozširirit obzory v oblastech týkajících se práce s lidmi a skupinami. Kniha také může sloužit jako vstupní brána $\mathrm{k}$ jednotlivým tématům, protože nabízí řadu odkazů na další zdroje, ve kterých může čtenář podrobněji poznávat jednotlivá témata.

Na knize Karla Paulíka je výjimečné, že často odkazuje na další české a slovenské texty. Čtenář si tak udělá povědomí o tom, kdo se v České republice a na Slovensku věnuje pracovní psychologii a může si přečíst snadno dostupné texty $\mathrm{v}$ mateřštině. Další silnou stránkou knihy je různorodost kapitol. Ty pokrývají jak čistě pracovně psychologická témata jako pracovní motivace, pracovní spokojenost nebo týmová práce, tak témata spadající pod specifické psychologické disciplíny jako psychologie reklamy nebo psychologie dopravy a témata patřící spíše do řízení lidských zdrojů jako bezpečnost práce nebo optimální pracovní podmínky.

Pro většinu českých knížek dotýkajících se pracovní psychologie bohužel platí, že staví zejména na starých teoriích a výzkumech. Kniha Karla Paulíka je v tomto výjimkou. I když se v jednotlivých kapitolách zabývá i historickými teoriemi, $v$ řadě př́ípadů je doplňuje o aktuální poznání. Čtenář se tak např́klad v kapitole o motivaci dočte nejen o teoriích potřeb, ale také o snahách o integraci motivačních teorií, ke kterým docházelo v uplynulých patnácti letech. Přesto existuje několik podle mě důležitých aktuálních poznatků, které se do souvisejících kapitol nevešly. Např́klad př́klon $\mathrm{k}$ teoriím etického leadershipu v oblasti vedení lidí nebo výstupy z meta-analýzy panelových studií věnujících se vztahu pracovní spokojenosti a výkonu. Na druhou stranu je potřeba říci, že problematika psychologie práce a organizace je široká a není možné do jedné přehledové knihy vměstnat všechny poznatky, které by někdo mohl považovat za důležité. Poznatky zvolené Karlem Paulíkem pokrývají klíčová témata a vychází z řady vlivných teorií, na kterých psychologie práce a organizace $\mathrm{v}$ minulosti stavěla nebo na kterých staví nyní.

J. Procházka doi: $10.14712 / 23366486.2019 .10$ 